University of Nebraska - Lincoln

DigitalCommons@University of Nebraska - Lincoln

January 2004

\title{
SEASONAL ACTIVITY AREAS OF COYOTES IN THE BEAR RIVER MOUNTAINS OF UTAH AND IDAHO
}

Glen F. Gantz

Utah State University

Frederick F. Knowlton

USDA/APHIS/WS National Wildlife Research Center

Follow this and additional works at: https://digitalcommons.unl.edu/icwdm_usdanwrc

Part of the Environmental Sciences Commons

Gantz, Glen F. and Knowlton, Frederick F., "SEASONAL ACTIVITY AREAS OF COYOTES IN THE BEAR RIVER MOUNTAINS OF UTAH AND IDAHO" (2004). USDA Wildlife Services - Staff Publications. 48.

https://digitalcommons.unl.edu/icwdm_usdanwrc/48

This Article is brought to you for free and open access by the U.S. Department of Agriculture: Animal and Plant Health Inspection Service at DigitalCommons@University of Nebraska - Lincoln. It has been accepted for inclusion in USDA Wildlife Services - Staff Publications by an authorized administrator of DigitalCommons@University of Nebraska - Lincoln. 


\title{
SEASONAL ACTIVITY AREAS OF COYOTES IN THE BEAR RIVER MOUNTAINS OF UTAH AND IDAHO
}

GLEN F. GANTZ, ${ }^{1}$ Department of Fisheries and Wildlife, Utah State University, Logan, UT 84322-5295, USA

FREDERICK F. KNOWLTON, ${ }^{2}$ U.S. Department of Agriculture, Wildlife Services, National Wildlife Research Center, Utah State University, Logan UT 84322-5295, USA

\begin{abstract}
We studied the seasonal movement patterns and dispersal of coyotes (Canis latrans) in the Bear River Mountains of northern Utah and southern Idaho to determine whether coyotes in this montane region exhibit an altitudinal migration on a seasonal basis. We used 3 locational parameters to assess whether a seasonal altitudinal migration was evident, including overlap in seasonal activity areas, distance between harmonic mean centers of activity, and seasonal differences in mean elevations of locations. Winter and summer activity areas of every mature coyote overlapped, with mean distances between harmonic centers of seasonal activity of $1.5 \mathrm{~km}$ ( range $=0.4-3.3$ $\mathrm{km})$. Conversely, there was no overlap between summer and winter activity areas of any subadult coyotes, with mean distances between their harmonic seasonal centers of activity of $35.8 \mathrm{~km}$ (range $=16.7-68.4 \mathrm{~km}$ ). Significant changes in elevation of seasonal locations were not evident for any sex or age group. We conclude that the movement of subadult coyotes in the Bear River Range was part of typical dispersal behavior and was not motivated by seasonal change, with such wandering generally ceasing during the coyotes' second year of age. We also conclude that adult coyotes utilized similar areas in summer as in winter, with no evidence of seasonal movements between mountain and locations at lower elevations.
\end{abstract}

JOURNAL OF WILDLIFE MANAGEMENT 69(4):1652-1659; 2005

Key words: aerial telemetry, Canis latrans, coyote, dispersal, Idaho, migration, mountains, radiotelemetry, seasonal movements, Utah.

Most previous studies of coyote activities in montane environments have primarily involved valley and riparian areas (Bowen 1982; Gese et al. 1996; Arjo and Pletscher 1999, 2004). Robinson and Cummings (1951) conducted an extensive tagging study in Yellowstone National Park, but the majority of their efforts also were directed primarily at riverine or valley populations. Exceptions to this generalization include Hawthorne (1970) and Shivik et al. (1997), who studied coyotes in the Sagehen Creek Basin of the Sierra Nevada. Based on observations in the intermountain area indicating coyotes are frequently found near concentrations of big game animals in winter (e.g., Nielsen 1975), conventional wisdom suggests coyotes in such areas migrate on a seasonal basis to lower elevations where food resources may be more accessible during winter (Nielsen 1975). On the other hand, coyotes are typically territorial year-round (Camenzind 1978, Windberg and Knowlton 1988, Gese et al. 1996, Arjo and Pletcher 1999, Knowlton et al. 1999, Blejwas 2002) and would be expected to defend those territories during courtship, breeding, and pup-rearing. Since pair-bonding among coyotes begins in late fall, continues through winter, with breeding occurring in late January

\footnotetext{
${ }^{1}$ Present address: InterWest Wildlife, Inc., 11255 North 2000 East, Richmond, UT 84333-1763, USA.

${ }^{2}$ Corresponding author e-mail: knowlton@cc.usu.edu
}

through February, biological constructs suggest they should defend territories in montane habitats even in rigorous winter conditions.

Inherent in addressing the issue of presence or absence of an altitudinal migration among coyotes in montane habitats is discrimination between migration and dispersal. Migration would anticipate a cyclic change in primary areas of activity, presumably on a seasonal basis. Dispersal, on the other hand, should involve individuals leaving 1 area of activity with an apparent intent of establishing another area of activity and not involve an attempt to reoccupy the former area. Dispersal is typically associated with, but not limited to, younger age classes (Davison 1980, Bowen 1982, Andelt 1985).

Interpretations take on added significance from the perspective that some coyotes are found at high elevations during winter near areas used by domestic sheep in summer. Sheep using these mountain grazing allotments are frequently preyed upon by coyotes (Klebenow and McAdoo 1976, Nass 1977, Taylor 1977, Tigner and Larson 1977, Wagner 1988, Wagner and Conover 1997). Efforts to curtail such depredations frequently rely on aerial gunning to remove coyotes from these allotments during winter when habitat and flying conditions make such activities safer and more effective. Detractors of such actions suggest coyote movements, as well as the 4- to 6-month interval between coyote removal and the presence of 
sheep, make it unlikely the appropriate coyotes are removed.

To explore biological aspects involved in this controversy, we used 3 parameters based on radio telemetry locations to assess whether or not coyotes inhabiting mountainous areas of northern Utah and southern Idaho are involved in altitudinal migrations on a seasonal basis, including overlap in seasonal telemetry locations, distances between harmonic mean seasonal centers of activities, and differences in elevation of seasonal locations.

\section{STUDY AREA}

Our study site consisted of $2,176 \mathrm{~km}^{2}$ of the Bear River Mountains straddling the Utah-Idaho border. It comprised portions of the Caribou and Wasatch-Cache National Forests and included some state and private lands. The topography is steep mountains, deep narrow canyons, and high mountain valleys and flats with elevations ranging from 1,425 $\mathrm{m}$ at the mouth of Logan Canyon to $3,042 \mathrm{~m}$ on Naomi peak. The climate was representative of semi-arid, high-desert mountains. The average, annual precipitation was $86 \mathrm{~cm}$, the majority of which occurred as snow. Annual snowfall averaged $756 \mathrm{~cm}$ (Brough et al. 1987) with the first permanent snowfall usually occurring in November and the ground remaining snow-covered until May or June (Schimpf et al. 1980, Brough et al. 1987). Average monthly temperatures ranged from a maximum of $24^{\circ} \mathrm{C}$ in July to a minimum of $-15^{\circ} \mathrm{C}$ in January (Brough et al. 1987).

The predominant vegetation varied from grassland-shrub communities on flat areas and southern exposures to coniferous forests at high elevations and northern exposures. Stands of aspen (Populus tremuloides), subalpine fir (Abies lasiocarpa), Douglas fir (Pseudotsuga menziesii), limber pine (Pinus flexilis), lodgepole pine (Pinus contorta), and big-toothed maple (Acer grandidentatum) were common. Shrub species included mountain mahogany (Cercocarpus ledifolius) and big sagebrush (Artemisia tridentata), and common graminoids were bluebunch wheatgrass (Agropyron spicatum), slender wheatgrass (A. trachycaulum), Idaho fescue (Festuca idahoensis), and mountain brome (Bromus carinatus). Nomenclature of vegetation follows Welch et al. (1987).

Mammalian co-inhabitants of the area included elk (Cervus elaphus), moose (Alces alces), mule deer (Odocoileus hemionus), badger (Taxidea taxus), striped skunk (Mephitis mephitis), snowshoe hare (Lepus americanus), porcupine (Erethizon dorsatum), red squirrel (Tamiasciurus hudsonicus), and various other rodents. While most ungulate species were found throughout the study area in summer, most moved to locations below $2,000 \mathrm{~m}$ in winter (Carpenter and Wallmo 1981, Wallmo and Regelin 1981).

\section{METHODS}

\section{Coyote Capture and Handling}

We conducted coyote capture efforts from 1 to 25 September 1987 and 14 August to 3 October 1988. The rugged nature of portions of the study area limited our trapping efforts to small areas (15-30 km of unimproved roads and trails) at any 1 time. To capture coyotes, we used Number 3 Victor foot-hold traps (Animal Trap Company, Letitz, Pennsylvania, USA) to which we attached tranquilizer trap devices (Balser 1965, Linhart et al. 1981, Sahr and Knowlton 2000) containing $600 \mathrm{mg}$ of propiopromazine hydrochloride to reduce capture injury and distress. We darted 1 animal from a helicopter (Baer et al. 1978) using a mixture of ketamine hydrochloride $(100 \mathrm{mg})$ and acepromazine $(1.0 \mathrm{mg})$. We used the same mixture to sedate animals for transport and handling. We took coyotes to the National Wildlife Research Center field station near Millville, Utah, or to a camp within the study area for handling and observation during recovery from the tranquilizer. We tagged coyotes in each ear with uniquely numbered metal tags, fitted them with 164-MHz radiotelemetry collars (Telonics, Inc., Mesa, Arizona, USA), extracted a premolar for age determination via counts of cementum annuli (Linhart and Knowlton 1967), as well recorded data on capture date, location, and sex. We typically held coyotes overnight and released them at their respective capture sites the following day.

\section{Data Collection}

We determined locations of radiocollared coyotes from fixed-wing aircraft, as described by Mech (1983), Knowlton (1995), and Gantz (1990) between 13 November 1987 and 15 September 1989. L. C. Stoddart (National Wildlife Research Center, personal communication) and G. F. Gantz (Utah State University, personal communication) calculated a mean operational error of the aerial telemetry locations at $101 \mathrm{~m}(\mathrm{SE}=17 \mathrm{~m})$ during a formal accuracy test in this topography. However, informal assessments made outside the test situation suggested locational errors during routine operations may have been twice as great. We de- 
termined daylight locations (typically morning) for each animal 1 to 10 times per month (0-2 per week), with greater emphasis on the summer grazing and winter aerial gunning periods. We identified aerial telemetry locations by visual reference to topographic features and recorded them on 1:24,000-scale U.S. Geological Survey topographic maps (Carrel et al. 1997) along with the date, time, and status (alive or dead) based upon motion-sensing circuitry in the transmitter.

\section{Data Analysis}

We identified radiotelemetry locations within 2 primary seasons of interest. Winter (1 Dec-31 Mar) coincided with the aerial-gunning season and the presence of continued snow pack, and summer (15 Jun-15 Sep) corresponded with the sheep grazing period.

We partitioned the location data for radiocollared coyotes by sex and age and assumed 15 April to be the date of birth for all coyotes on the study area. Data collection was clustered during winter and summer periods to enhance interseasonal comparisons among the following age classes: juveniles in winter and yearlings in summer (9-18.5 months), yearlings in summer and the following winter (15.5-24.5 months), yearlings in winter and adults in summer (21-30.5 months), and adults between summer and winter ( $\geq 27.5$ months).

We assigned universal transverse mercator (UTM) coordinates and elevation for each location. We calculated the seasonal activity areas and harmonic mean centers of activity for each radiocollared coyote with program HOME RANGE (Samuel et al. 1985a), which uses an extension of the harmonic mean measure of activity (Dixon and Chapman 1980). HOME RANGE determines a utilization distribution by estimating the probability of use at any location in the activity area (Samuel et al. 1985a). Harmonic mean centers of activity indicate the true centers of activity (Dixon and Chapman 1980). Some locations were identified as outliers by program HOME RANGE based on having bivariate normal weights $<0.6$ (i.e., distances to the other locations were great). Since outliers disproportionately affect estimates of activity area size, we excluded them from the analyses and from subsequent calculations (Samuel and Garton 1985; Samuel et al. 1985a,b). We then defined activity areas by the area encompassed by the $85 \%$ harmonic utilization contour, excluding those comprised of $<10$ locations from the analysis to reduce errors associated with small sample sizes (Samuel et al. 1985a).
We used coyotes for which we determined activity areas in consecutive seasons to determine whether coyotes may have migrated on a seasonal basis. We combined plots from adjoining seasons for each animal and examined them visually to determine whether activity area contours overlapped. When displayed graphically, the pattern of distances between seasonal harmonic mean centers of activity as a function of animal age were sufficiently distinct to preclude the need for inferential statistics (Cherry 1998, Johnson 1999). We also visually examined changes in mean elevations of locations for each animal on a seasonal basis.

\section{RESULTS}

\section{Characteristics of the Data}

We captured 21 coyotes, 2 juveniles $(1 \mathrm{M}, 1 \mathrm{~F})$ and 1 adult (M) in 1987, and 8 juveniles (4M, 4F), 8 yearlings (4M, 4F), and 2 adults $(1 \mathrm{M}, 1 \mathrm{~F})$ in 1988 (Table 1). We monitored individual radiocollared coyotes for zero to 23.7 months $(\bar{x}=8.9, \mathrm{SD}=5.9)$; 10 of which died before completion of the study, and 4 moved off the study area. Three of these moved to sites physiographically similar to the study area, while a fourth moved into farmland but returned 2 weeks later.

\section{Area of Use}

We used data from 16 coyotes $(8 \mathrm{M}, 8 \mathrm{~F})$ with $\geq 10$ locations within at least 1 season to assess relative size of their seasonal activity areas (Table 1). The numbers of locations used to determine seasonal activity areas for individual coyotes ranged from 10 to $28(\bar{x}=18.5$, SD $3.23, n=30)$, with $\leq 3(\bar{x}=$ $0.80, \mathrm{SD}=1.00, n=29)$ outliers identified by program HOME RANGE.

The mean size of activity areas decreased nearly 7-fold with age, from $71 \mathrm{~km}^{2}$ among juveniles during their first winter, to $10 \mathrm{~km}^{2}$ among adult coyotes (Fig. 1). Activity areas of coyotes $<19$ months old were larger than coyotes $\geq 19$ months old (Fig. 1). Variance in mean size of activity areas also decreased with coyote age (Fig. 1).

We used data from 11 coyotes $(5 \mathrm{M}, 6 \mathrm{~F})$ to assess inter-seasonal movement patterns (Table 2). Information from 2 coyotes spanned 4 and 3 seasons, respectively, permitting 5 interseasonal comparisons between them. Twelve of 14 interseasonal activity area comparisons were winter to summer. The 3 parameters we used to assess interseasonal movement patterns were: (1) seasonal overlap in activity areas, (2) distance between harmonic centers of activity, and (3) changes in mean elevation. One 
Table 1. Age, sex, tenure in study, and number of radiolocations obtained on coyotes in the Bear River Mountains, Utah, USA, $1987-1989$.

\begin{tabular}{|c|c|c|c|c|c|c|c|}
\hline \multirow{3}{*}{$\begin{array}{c}\text { Animal } \\
\text { no. }\end{array}$} & \multirow[b]{3}{*}{ Sex } & \multirow[b]{3}{*}{$\mathrm{Age}^{\mathrm{a}}$} & \multirow{3}{*}{$\begin{array}{c}\text { Tenure in } \\
\text { study (mo.) }\end{array}$} & \multicolumn{4}{|c|}{ No. of radiotelemetry locations } \\
\hline & & & & \multicolumn{2}{|c|}{$1987-1988$} & \multicolumn{2}{|c|}{ 1988-1989 } \\
\hline & & & & Winter & Summer & Winter & Summer \\
\hline 1 & M & Juvenile & 4.7 & 20 & & & \\
\hline 2 & $\mathrm{M}$ & Juvenile & 7.0 & & & 16 & \\
\hline 3 & M & Juvenile & 12.6 & & & 18 & 16 \\
\hline 4 & $\mathrm{~F}$ & Juvenile & 11.6 & & & 16 & 19 \\
\hline 5 & $\mathrm{~F}$ & Juvenile & 11.9 & & & 17 & 21 \\
\hline 6 & $\mathrm{~F}$ & Juvenile & 17.5 & & 19 & 17 & 21 \\
\hline 7 & $\mathrm{~F}$ & Juvenile & 23.7 & 28 & 19 & 19 & 21 \\
\hline 8 & M & Yearling & 11.5 & & & 16 & 21 \\
\hline 9 & $\mathrm{M}$ & Yearling & 11.9 & & & 17 & 21 \\
\hline 10 & M & Yearling & 13.0 & & 5 & 19 & 21 \\
\hline 11 & $\mathrm{~F}$ & Yearling & 4.3 & & & 10 & \\
\hline 12 & $\mathrm{~F}$ & Yearling & 7.6 & & & 16 & 2 \\
\hline 13 & $\mathrm{~F}$ & Yearling & 11.8 & & & 16 & 20 \\
\hline 14 & $M$ & Adult & 4.1 & 13 & & & \\
\hline 15 & $\mathrm{M}$ & Adult & 11.4 & & & 17 & 22 \\
\hline 16 & $\mathrm{~F}$ & Adult & 11.6 & & & 17 & 21 \\
\hline
\end{tabular}

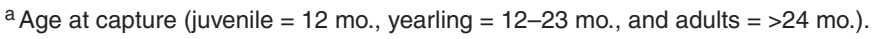

coyote traversed a very large area during the summer of 1989 and was excluded from this analysis.

Activity areas from adjacent seasons for individual coyotes overlapped in $64 \%$ of the comparisons. One of 2 yearling-yearling, all yearling-adult, and all adult-adult comparisons had overlapping activity areas between seasons. None of the juvenile-yearling comparisons nor the other yearling-yearling comparison had overlapping activity areas in adjacent seasons (Table 2).

Mean distances between harmonic centers of activity for inter-seasonal comparisons among age classes ranged from $0.4 \mathrm{~km}$ (yearling-adult) to 68.4 km (juvenile-yearling; Table 2). The difference in the mean distance between seasonal centers of activity of coyotes $<19$ months old (juvenile-yearling) and those $\geq 19$ months old (yearling-adult and

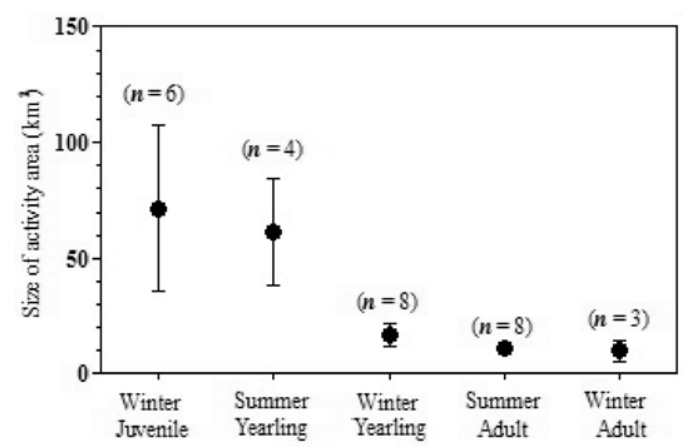

Fig. 1. Comparison of mean sizes $\left(\mathrm{km}^{2}\right)$ of seasonal activity areas by age class of radiocollared coyotes in the Bear River Mountains, Utah and Idaho, USA, 1987-1988 (samples sizes and SE are indicated). adults) is evident (Fig. 2). Mean distances between seasonal centers of activity for coyotes $<19$ months old $(\bar{x}=35.8 \mathrm{~km}, \mathrm{SE}=11.3, n=4)$ was 24 times larger than the mean for coyotes $\geq 19$ months old ( $\bar{x}=1.5$ $\mathrm{km}, \mathrm{SE}=0.3, n=8)$. There also was greater variation in distances between seasonal centers of activity for younger coyotes than older ones (Fig. 2).

Inter-seasonal changes in the mean elevations of locations for individual coyotes ranged from -500 $\mathrm{m}$ (juvenile-yearling) to $+400 \mathrm{~m}$ (yearling-yearling; Fig. 3). Although differences were not large, mean elevations of locations for 9 of 14 coyotes appeared slightly higher in winter than in summer. No relationship between change in elevation and age or sex was evident.

\section{Dispersal Patterns}

Coyotes that moved long distances traveled primarily north and south, paralleling the axis of the Bear River Range, rather than east-west. The latter could have moved them into valleys on either side of the range. The harmonic center of activity for 4 coyotes shifted 11.8, 16.7, 27.8, and $68.4 \mathrm{~km}$ south, respectively, while 1 coyote shifted $30.4 \mathrm{~km}$ north. The maximum separation of locations for 2 coyotes were 81.8 and $129.5 \mathrm{~km}$ in 150 and 44 days, respectively, in north-south directions.

\section{DISCUSSION}

\section{Characteristics of Activity Areas}

We did not acquire sufficient telemetry locations to describe home-range characteristics in any con- 
Table 2. Comparisons of interseasonal activity areas of coyotes, by age class, in the Bear River Mountains of Utah and Idaho, USA, 1987-1989.

\begin{tabular}{|c|c|c|c|c|c|}
\hline $\begin{array}{c}\text { Animal } \\
\text { no. }\end{array}$ & Sex & Age & Season ${ }^{a}$ & $\begin{array}{l}\text { Overlap in } \\
\text { seasonal } \\
\text { ranges }^{b}\end{array}$ & $\begin{array}{c}\text { Distance }(\mathrm{km}) \\
\text { between centers } \\
\text { of activityc }^{\mathrm{c}}\end{array}$ \\
\hline 3 & $M$ & Juvenile-yearling & Winter-summer & No & 68.4 \\
\hline 4 & $\mathrm{~F}$ & Juvenile-yearling & Winter-summer & No & 30.4 \\
\hline 5 & $\mathrm{~F}$ & Juvenile-yearling & Winter-summer & No & 27.8 \\
\hline 7 & $\mathrm{~F}$ & Juvenile-yearling & Winter-summer & No & 16.7 \\
\hline 6 & $\mathrm{~F}$ & Yearling-yearling & Summer-winter & No & 11.8 \\
\hline 7 & $\mathrm{~F}$ & Yearling-yearling & Summer-winter & Yes & 2.3 \\
\hline 7 & $\mathrm{~F}$ & Yearling-adult & Winter-summer & Yes & 2.1 \\
\hline 8 & M & Yearling-adult & Winter-summer & Yes & 1.7 \\
\hline 6 & $\mathrm{~F}$ & Yearling-adult & Winter-summer & Yes & 1.6 \\
\hline 9 & $M$ & Yearling-adult & Winter-summer & Yes & 1.2 \\
\hline 13 & $\mathrm{~F}$ & Yearling-adult & Winter-summer & Yes & 0.6 \\
\hline 10 & $M$ & Yearling-adult & Winter-summer & Yes & 0.4 \\
\hline 15 & $M$ & Adult-adult & Winter-summer & Yes & 3.3 \\
\hline 16 & $\mathrm{~F}$ & Adult-adult & Winter-summer & Yes & 0.9 \\
\hline
\end{tabular}

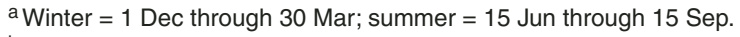

${ }^{b}$ Based on $85 \%$ utilization contour from program HOME RANGE (Samuel, et al. 1985a).

${ }^{\mathrm{C}}$ Based on harmonic mean from program HOME RANGE (Samuel, et al. 1985a).

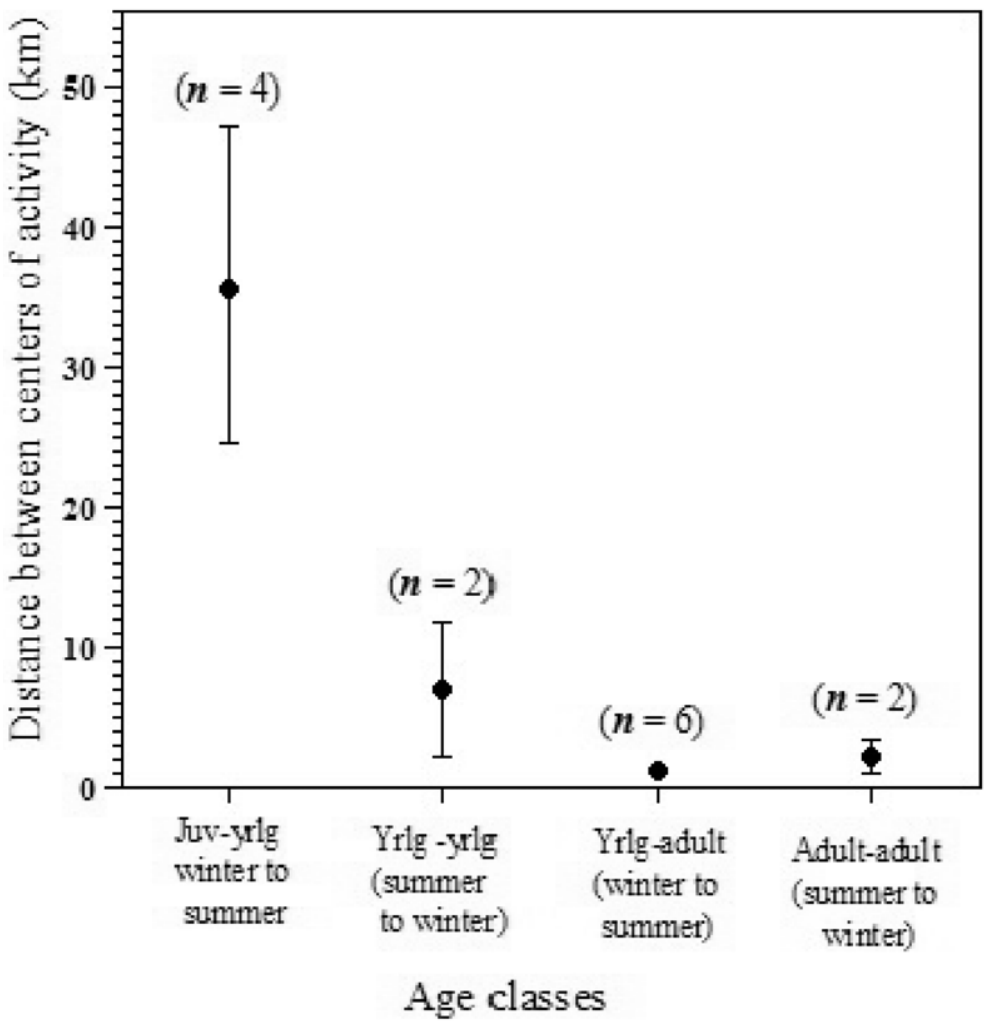

Fig. 2. Mean distance between seasonal harmonic mean centers of activity $(\mathrm{km})$ by age class for radiocollared coyotes in the Bear River Mountains, Utah and Idaho, USA, 1987-1988 (sample sizes and SE are indicated). ventional sense. However, we could readily categorize the coyotes we monitored into 1 group that had relatively large activity areas and another with much smaller activity areas. Similarly, we also could readily discriminate between coyotes that made appreciable changes in areas of activity from 1 season to the next and those that did not. With 1 exception, the 2 processes segregated the coyotes into groups that were identical and consistent with the relative ages of the animals. Activity areas for coyotes 8 to 17 months old were appreciably larger than those $>19$ months old. In addition, in the year following being radiocollared all coyotes $<6$ months old at the time also exhibited a significant change in centers of activity ( $\bar{x}$ displacements $=35 \mathrm{~km}$ ), while the changes in mean centers of activity we observed among older coyotes was only $1.5 \mathrm{~km}$. Furthermore, we are not aware any of our juvenile coyotes returned to an original activity area. We consider the changes in activity areas among younger coyotes to be dispersal activities and unrelated to migration. This interpretation is consistent with the timing of major dispersal activities of coyotes described by others (Davison 1980, Bekoff and Wells 1982, Bowen 1982, Pyrah 1984, and Andelt 1985). 
We interpret the data indicating summer and winter activity areas of coyotes in our study overlapped and the relatively short change noted in the mean change of summer and winter activity areas to infer that adult coyotes in this area do not migrate on a seasonal basis. This is supported by only slight changes in the mean elevations where the animals were located on a seasonal basis. If anything, elevations of estimated for winter locations were slightly higher than those calculated for summer locations. We conclude that adult, territorial coyotes in this

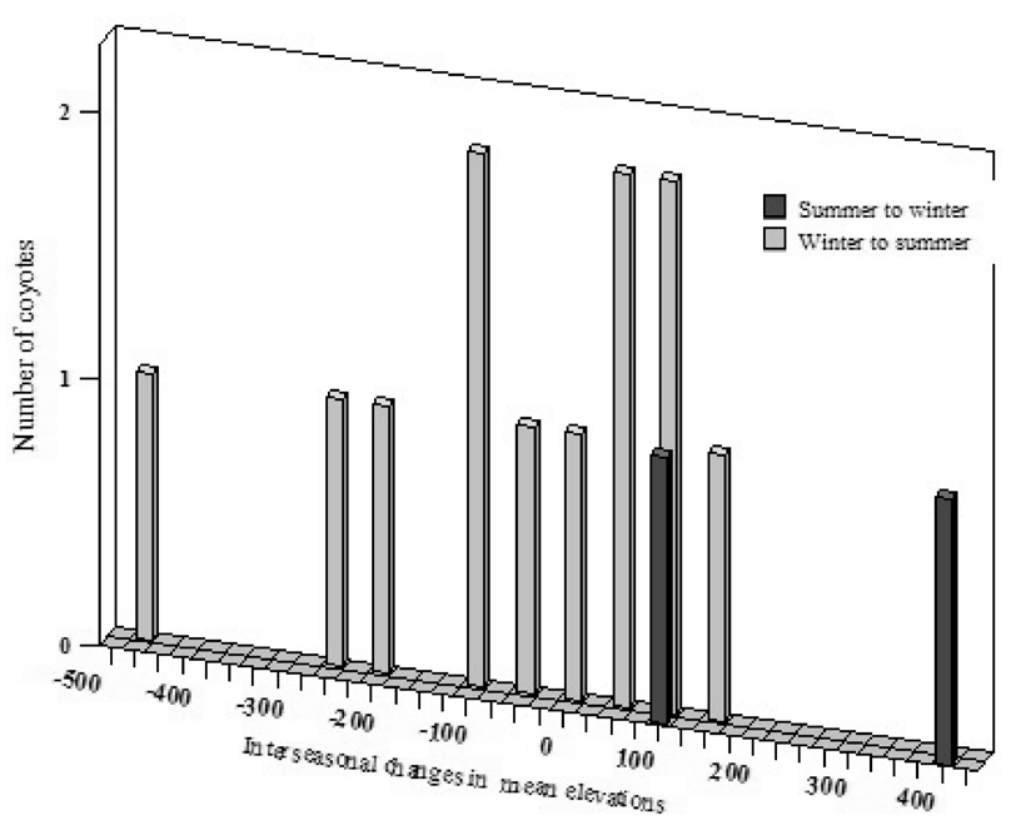

Fig. 3. Change in mean elevation (m), in 50-m increments, between summer and winter locations of radiocollared coyotes in the Bear River Mountains, Utah and Idaho, USA, 1987-1989. area do not exhibit an altitudinal migration but maintain the same territories year-round. This is consistent with other research indicating coyotes maintain the same territories throughout the year (Camenzind 1978, Bowen 1981, Andelt 1985, Shivik 1995, Gese et al. 1996, Shivik et al. 1997) as well as with Weaver's (1979) suggestion that coyotes live in summer where they can survive in winter.

\section{Dispersal Patterns}

All dispersal type movements we observed paralleled the axis of the Bear River Mountains. If these coyotes had moved similar distances perpendicular to the axis of the mountains, many would have moved to valley locations at much lower elevations and presumably less rigorous environmental conditions. Only 1 coyote left the mountains, and that was for only a 2-week period in summer when it was located in foothill farmlands. Dispersing coyotes that traveled long distances did not leave montane habitats nor high elevations during winter. It appears that coyotes inhabiting mountains may be somewhat distinct from coyotes living in nearby valleys. This appears consistent with tagging studies of Robinson and Cummings (1951) where most coyotes tagged in valley locations were recovered in valley locations even though some moved considerable distances. Our observations are also consistent with that of

Sacks et al. $(2004,2005)$ who used molecular genetic analyses to suggest genetic distances of coyotes are greater between adjacent bioregions than within bioregions. If correct, this may imply that coyotes imprint on natal habitat or topographic characteristics and seek similar areas when trying to establish territories of their own.

Knowing that many coyotes stay at high elevations during rigorous winter conditions increases our curiosity about how they subsist. Shivik et al. (1997) indicated coyotes in such situations reduce total activity, possibly to conserve energy. On the other hand, Weaver (1979) suggested the summer distribution of coyotes within Jackson Hole (Wyoming) reflected the winter distribution of ungulates, and presumably ungulate carrion. On several occasions we noted coyotes digging through 2-3 $\mathrm{m}$ of packed snow to retrieve parts of deer carcasses at a time when deer were not in the vicinity. Carcasses of unretrieved deer from the hunting season may permit coyotes to survive such rigorous conditions and occupy a niche that might otherwise be uninhabitable. This is consistent with observations of Todd and Keith (1976) and Weaver (1979) suggesting availability of winter carrion can be a major factor in maintaining coyote populations in the more harsh climates typical of northern portions of coyote distribution. 
Our interpretations are subject to the cautions associated with small sample sizes in terms of the number of radiocollared coyotes involved and the number of radio locations used to assess characteristics of their activity areas. We believe, however, the nature of the data is sufficiently compelling to warrant consideration in management programs as well as future research designs pending development of more definitive information.

\section{MANAGEMENT IMPLICATIONS}

Current coyote management programs in mountainous areas of the west revolve primarily around reducing depredations on the domestic stock that use such grazing allotments in summer. This frequently entails removing coyotes via aerial gunning, typically in winter when foliage is less dense and high altitude flying conditions more safe. Other research indicates alpha coyotes in territorial social groups cause most depredations on sheep (Sacks et al. 1999, Blejwas 2002), especially those nurturing pups (Till and Knowlton 1983, Bromley and Gese 2001). Our data suggest coyotes removed from mountain pastures in winter include the territorial coyotes apt to be present the following summer. The later in the winter period coyotes are removed, the less likely territories will be re-populated by other territorial, and potentially reproductive, coyotes. We recommend coyote removal efforts be directed in close proximity to the grazing allotments in need of depredation relief and as late in the winter season as practical. Based on current understandings, we believe management programs for coyotes in mountainous regions need not incorporate special biological considerations with regard to seasonal movements compared to other environmental situations.

\section{ACKNOWLEDGMENTS}

We are indebted to L. C. Stoddart for his generous technical assistance and advice throughout the field study. Similarly, the assistance of S. R. Olmstead, S. M. Ebbert, G. Dasch, A. J. Kriwox, and J. Theade is appreciated for assisting with capturing coyotes. Personnel from the Logan Ranger District of the Cache National Forest and the Montpelier Ranger District of the Caribou National Forest granted permission to use lands under their jurisdiction and helped alleviate apprehensions among Wildlife Services personnel and sheep grazing permittees. We also thank J. Shivik, M. Jaeger, M. Conner, and several anonymous reviewers for critiquing drafts of this manuscript. The project was supported by the National Wildlife Research Cen- ter (NWRC) within the Wildlife Services program of the United States Department of Agriculture under Cooperative Research Agreement 12-16-740079, with oversight by the Institutional Animal Care and Use Committee of NWRC.

\section{LITERATURE CITED}

Andelt, W. F. 1985. Behavioral ecology of coyotes in south Texas. Wildlife Monographs 94.

Arjo, W. M., AND D. H. Pletscher. 1999. Behavioral responses of coyotes to wolf recolonization in northwest Montana. Canadian Journal of Zoology 77:1919-1927.

- AND 2 2004. Coyote and wolf habitat use in northwest Montana. Northwest Science 78:24-32.

Baer, C. H., R. E. SEverson, AND S. B. LinharT. 1978. Live capture of coyotes from a helicopter with ketamine hydrochloride. Journal of Wildlife Management 42:452-454.

BALSER, D. S. 1965. Tranquilizer tabs for capturing wild carnivores. Journal of Wildlife Management 29:438-442.

Bekoff, M., AND M. C. WeLls. 1982. Behavioral ecology of coyotes: social organization, rearing patterns, space use, and resource defense. Zeit Tierpsychology 60:281-305.

BLEJWAS, K. M. 2002. Selective removal of breeding coyotes: effects on sheep predation and the social, genetic, and spatial relationships of coyotes. Dissertation, University of California, Berkeley, USA.

Bowen, W. D. 1981. Variation in coyote social organization: the influence of prey size. Canadian Journal of Zoology 59:639-652.

_ 1982. Home range and spatial organization of coyotes in Jasper National Park, Alberta. Journal of Wildlife Management 46:201-216.

BROMLEY, C., AND E. M. GESE. 2001. Surgical sterilization as a method of reducing coyote depredation on domestic sheep. Journal of Wildlife Management 65:510-519.

Brough, R. C., D. L. Jones, and D. J. Stevens. 1987. Utah's comprehensive weather almanac. Publishers Press, Salt Lake City, Utah, USA.

CAmenzind, F. J. 1978. Behavioral ecology of coyotes on the National Elk Refuge, Jackson, Wyoming. Pages 267-294 in M. Bekoff, editor. Coyotes: biology, behavior, and management. Academic Press, New York, USA.

Carpenter, L. H., And O. C. Wallmo. 1981. Rocky Mountain and intermountain habitats: part 2. Habitat evaluation and management. Pages 399-421 in O. C. Wallmo, editor. Mule and black-tailed deer of North America. Wildlife Management Institute and U.S. Forest Service, University of Nebraska Press, Lincoln, USA.

Carrel, W. K., R. A. Ockenfels, J. A. Wennerlund, and J. C. Devos, JR. 1997. Topographic mapping, Loran-C, and GPS accuracy for aerial telemetry locations. Journal of Wildlife Management 61:1406-1412.

Cherry, S. 1998. Statistical tests in publications of The Wildlife Society. Wildlife Society Bulletin 26:947-953.

DAVISON, R. P. 1980. The effect of exploitation on some parameters of coyote populations. Dissertation, Utah State University, Logan, USA.

Dixon, K. R., AND J. A. CHAPMAN. 1980. Harmonic mean measure of animal activity areas. Ecology 61:1040-1044.

GANTZ, G. F. 1990. Seasonal movement patterns of coy- 
otes in the Bear River Mountains of Utah and Idaho. Thesis, Utah State University, Logan, USA.

Gese, E. M., R. L. Ruff, ANd R. L. Crabtree. 1996. Foraging ecology of coyotes (Canis latrans): the influence of extrinsic factors and a dominance hierarchy. Canadian Journal of Zoology 74:769-783.

HaWTHORNe, V. M. 1970. Movements and food habits of coyotes in the Sagehen Creek Basin and vicinity. Thesis, University of Nevada, Reno, USA.

JoHnson, D. H. 1999. The insignificance of statistical significance testing. Journal of Wildlife Management 63:763-772.

Klebenow, D. A., And K. McAdoo. 1976. Predation on domestic sheep in northeastern Nevada. Journal of Range Management 29:96-100.

KNowLton, F. F. 1995. Radio-telemetry as a wildlife research tool. Pages 81-106 in S. H. Berwick and V. B. Saharia, editors. The development of international principles and practices of wildlife research and management: Asian and American approaches. Oxford University Press, Delhi, India.

, E. M. Gese, AND M. M. Jaeger. 1999. Coyote depredation control: an interface between biology and management. Journal of Range Management 52:398-412.

Linhart, S. B., G. J. Dasch, And F. J. Turkowski. 1981. The steel leg-hold trap: techniques for reducing foot injury and increasing selectivity. Pages 1560-1578 in J. A. Chapman and D. Pursley, editors. Worldwide Furbearer Conference Volume 3, Frostburg, Maryland, USA.

—, AND F. F. KNOWLTON. 1967. Determining age of coyotes by tooth cementum layers. Journal of Wildlife Management 31:362-365.

MECH, L. D. 1983. Handbook of animal radio-tracking. University of Minnesota Press, Minneapolis, USA.

NAss, R. D. 1977. Mortality associated with sheep operations in Idaho. Journal of Range Management 30:253-258.

Nielsen, D. B. 1975. Coyotes and deer. Utah Science 38:87-90.

PYRAH, D. 1984. Social distribution and population estimates of coyotes in north-central Montana. Journal of Wildlife Management 48:679-690.

Robinson, W. B., AND M. W. Cummings. 1951. Movements of coyotes from and to Yellowstone National Park. U.S. Fish and Wildlife Service, Special Scientific Report, Wildlife Number 11:1-17.

SAcks, B. N., S. K. Brown, AND H. B. Ernest. 2004. Population structure of California coyotes corresponds to habitat-specific breaks and illuminates species history. Molecular Ecology 13:1265-1275.

- B. R. Mitchell, C. L. Williams, and H. B. ERNEST. 2005. Coyote movements and social structure along a cryptic population genetic subdivision. Molecular Ecology 1241-1249.

, M. M. Jaeger, J. C. C. NeAle, And D. R. McCulLOUGH. 1999. Territoriality and breeding status of coyotes relative to sheep predation. Journal of Wildlife Management 63:593-605.

SAHR, D. P., AND F. F. KNowlton. 2000. Evaluation of tranquilizer trap devices (TTDs) for foothold traps used to capture gray wolves. Wildlife Society Bulletin 28:597-605.
SAmuel, M. D., AND E. O. GARTON. 1985. Home range: a weighted normal estimate and test of underlying assumptions. Journal of Wildlife Management 49:513-519.

, D. J. Pierce, E. O. Garton, L. J. Nelson, and K. R. DIXON. 1985a. User's manual for program HOME RANGE. University of Idaho Forest, Wildlife, and Range Experiment Station, Technical Report 15. Moscow, USA.

-. $1985 b$ Identifying areas of concentrated use within the home range. Journal of Animal Ecology 54:711-719.

Schimpf, D. J., J. A. Henderson, and J. A. MacMahon. 1980. Some aspects of succession in the spruce-fir forest zone of northern Utah. Great Basin Naturalist 40:1-25.

SHIVIK, J. A. 1995. Factors influencing space use and activity of Sagehen Basin coyotes. Thesis, University of California, Berkeley, USA.

—_, M. M. Jaeger, ANd R. H. Barrett. 1997. Coyote activity patterns in the Sierra Nevada. Great Basin Naturalist 57:355-358.

TAYLOR, R. G. 1977. An economic analysis of predation control and predatory sheep losses in southwestern Utah. Thesis, Utah State University, Logan, USA.

Tigner, J. R., AND G. E. LARSON. 1977. Sheep losses on selected ranches in southern Wyoming. Journal of Range Management 30:244-252.

TiLl, J. A., and F. F. KNOWLTON. 1983. Efficacy of denning in alleviating coyote depredation upon domestic sheep. Journal of Wildlife Management 47:1018-1025.

TodD, A. W., and L. B. KeITH. 1976. Responses of coyotes to winter reductions in agricultural carrion. Wildlife Technical Bulletin Number 5. Alberta Recreation, Parks, and Wildlife, Canada.

WAGneR, F. H. 1988. Predator control and the sheep industry: the role of science in policy formation. Regina Books, Claremont, California, USA.

WAGNER, K. K., AND M. R. ConOvER. 1997. Effect of preventive coyote hunting on sheep losses to coyote predation. Journal of Wildlife Management 63:606-612.

Wallmo, O. C., AND W. L. Regelin. 1981. Rocky Mountain and intermountain habitats: Part 1. Food habits and nutrition. Pages 387-398 in O. C. Wallmo, editor. Mule and black-tailed deer of North America. Wildlife Management Institute and U.S. Forest Service, University of Nebraska Press, Lincoln, USA.

WEAVER, J. L. 1979. Influence of elk carrion upon coyote populations in Jackson Hole, Wyoming. Pages 152-157 in M. S. Boyce and L. D. Hayden-Wing, editors. Symposium on North American elk: ecology, behavior, and management. University of Wyoming Press, Laramie, USA.

Welch, S. L., N. D. Atwood, L. C. Higgins, and S. GoOdRICH. 1987. A Utah flora. Great Basin Naturalist Memoir Number 9.

WindBerg, L. A., AND F. F. KNowlton. 1988. Management implications of coyote spacing patterns in southern Texas. Journal of Wildlife Management 52:632-640.

Associate Editor: Morgart. 